July 1999 • NREL/SR-540-24146

\title{
Using LNG as a Fuel in Heavy-Duty Tractors
}

Liquid Carbonic, Inc.

Willis, Texas

Trucking Research Institute Alexandria, Virginia

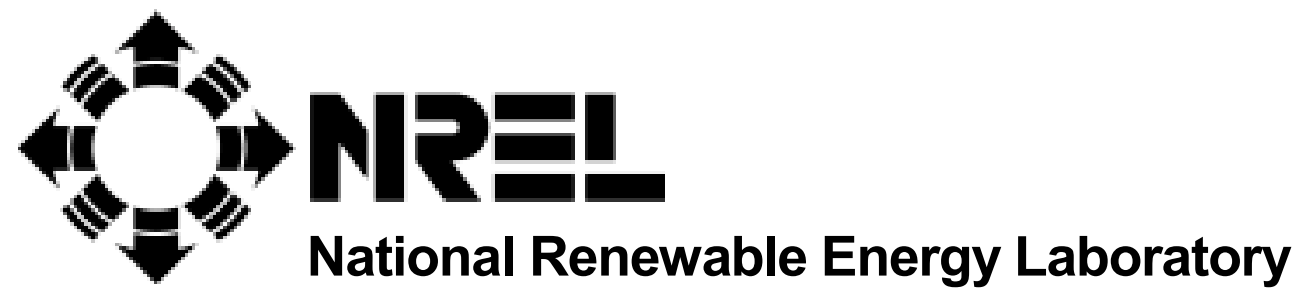

1617 Cole Boulevard Golden, Colorado 80401-3393

NREL is a U.S. Department of Energy Laboratory Operated by Midwest Research Institute $\bullet$ Battelle $\bullet$ Bechtel 
July 1999 • NREL/SR-540-24146

\section{Using LNG as a Fuel in Heavy-Duty Tractors}

Liquid Carbonic, Inc.

Willis, Texas

Trucking Research Institute

Alexandria, Virginia

NREL Technical Monitor: M. Frailey

Prepared under Subcontract No. RAC-4-1445-1

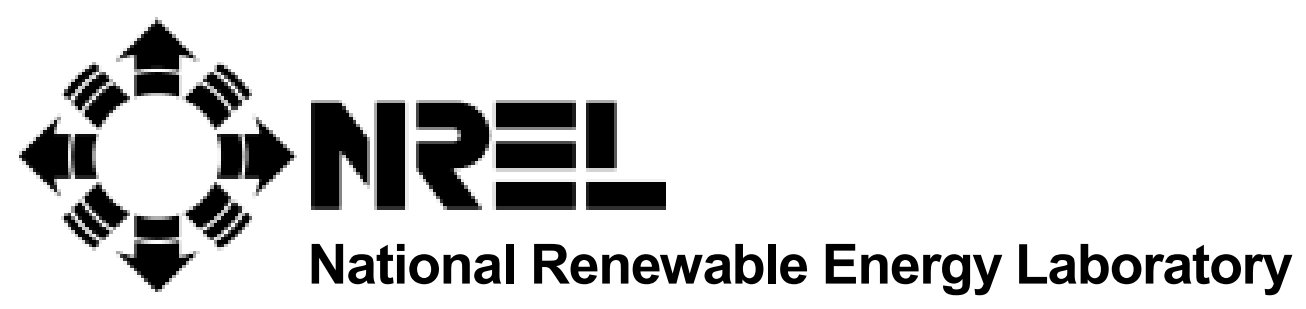

1617 Cole Boulevard

Golden, Colorado 80401-3393

NREL is a U.S. Department of Energy Laboratory

Operated by Midwest Research Institute $\bullet$ Battelle $\bullet$ Bechtel

Contract No. DE-AC36-98-G010337 


\section{NOTICE}

This report was prepared as an account of work sponsored by an agency of the United States government. Neither the United States government nor any agency thereof, nor any of their employees, makes any warranty, express or implied, or assumes any legal liability or responsibility for the accuracy, completeness, or usefulness of any information, apparatus, product, or process disclosed, or represents that its use would not infringe privately owned rights. Reference herein to any specific commercial product, process, or service by trade name, trademark, manufacturer, or otherwise does not necessarily constitute or imply its endorsement, recommendation, or favoring by the United States government or any agency thereof. The views and opinions of authors expressed herein do not necessarily state or reflect those of the United States government or any agency thereof.

Available to DOE and DOE contractors from:

Office of Scientific and Technical Information (OSTI)

P.O. Box 62

Oak Ridge, TN 37831

Prices available by calling 423-576-8401

Available to the public from:

National Technical Information Service (NTIS)

U.S. Department of Commerce

5285 Port Royal Road

Springfield, VA 22161

$703-605-6000$ or $800-553-6847$

or

DOE Information Bridge

http://www.doe.gov/bridge/home.html

Printed on paper containing at least $50 \%$ wastepaper, including $20 \%$ postconsumer waste 


\section{Contents}

EXECUTIVE SUMMARY




\section{Executive Summary}

The U.S. Department of Energy (DOE) has designated the National Renewable Energy Laboratory (NREL) as the "field manager" for implementing certain portions of the Alternative Motor Fuels Act of 1988. Section 400BB of the Act makes a commitment to develop and evaluate alternative fuels in heavy-duty vehicles.

By the early 1990s the passenger car, light-duty truck, and transit bus segments of the automotive industry had all accumulated some experience with natural gas, but there was very little experience with natural gas in heavy-duty (line-haul) automotive applications. In 1994, NREL contracted with the Trucking Research Institute (TRI) to obtain a cooperative agreement with Liquid Carbonic. The purpose of this agreement was to (1) purchase and operate liquid natural gas- (LNG-) powered heavy-duty tractor-trailers with prototype Detroit Diesel Corporation (DDC) Series 60 natural gas (S60G) engines in over-the-road commercial service applications; and (2) collect and provide operational data to DDC to facilitate the on-road prototype development of the engine and to NREL for the Alternative Fuels Data Center.

The vehicles operated from August 1994 through April of 1997 and led to a commercially available, emissions-certified S60G in 1998. This report briefly documents the engine development, the operational characteristics of LNG, and the lessons learned during the project. 


\section{Background}

In early 1992, one of the largest transit bus operations in the country, the Metropolitan Transit Authority of Harris County, Texas, (Houston Metro), decided to convert its entire fleet of transit buses to natural gas. This was years ahead of a Texas law (Appendix A) that requires a phasedin conversion to alternative fuels by metropolitan transit authorities. This law limited alternative fuel choices to natural gas, propane, or electricity. With the selection of LNG in April 1992, Houston Metro awarded Liquid Carbonic a 7-year fuel supply contract. To produce and distribute the LNG required for the Houston Metro buses and the Greater Austin Bus Company, which also opted to convert to LNG, Liquid Carbonic began to purchase large sources of natural gas and to construct a new facility in Willis, Texas. During construction of the Willis plant, Liquid Carbonic supplied LNG to its growing list of customers from a plant in Geismar, Louisiana. The Willis plant was designed to produce approximately 100,000 gallons per day when it was completed in 1994.

With the plant's completion, Liquid Carbonic took the lead in U.S. LNG production. Because the Willis facility was built to supply and sell LNG exclusively for transit bus fleets and heavyduty trucks, Liquid Carbonic decided it should use LNG-powered trucks for the distribution fleet. Four Freightliner LNG-fueled tractors, with DDC S60G engines, were leased from Ruan Transportation Management Systems (RTMS). Three were operated in the distribution fleet and the fourth was used for demonstration and show purposes.

Experience with LNG-fueled engines was limited at that time and did not include heavy-duty truck fleet operations. These were some of the first tractors powered by the prototype DDC S60G engine. The design of the engine/chassis combination was based on "best practices" engineering - there were no industry standards or regulations at the time. The vehicle's costs were substantially higher than those of their diesel counterpart, (which was reflected in the lease cost), but Liquid Carbonic's commitment to leasing the LNG tractors was unwavering. The goal for this vehicle fleet to set an example for the industry.

\section{Equipment}

\section{Engines}

Many of the 12.7L, 6-cylinder, DDC S60G engine components are common with the Series 60 diesel (S60) version. The engine block, cylinder liners, pistons, and cooling and lubricating systems are identical. They also share the features of a waste-gated turbo-charger, air-to-air aftercooling, lean-burn combustion, and a DDC electronic engine control module (DDEC). The S60G crankshaft, camshaft, connecting rods, and exhaust system are modified variations from the S60.

The big differences between the S60G and the S60 are the compression ratio (c/r) and the fuel delivery and ignition systems. The S60G has a 10:1 c/r, single point (prior to the throttle plate) fuel injection, and spark ignition of the air/fuel mixture. The S60 has a 15:1 c/r, multipoint (directly into the cylinder) fuel injection and ignites the air/fuel mixture by the heat of compression. The S60G engine has a rating of $370 \mathrm{hp}$ at $1800 \mathrm{rpm}$ and the $\mathrm{S} 60$ engines are sold 
in ratings of $350 \mathrm{hp}$ and $370 \mathrm{hp}$ at $1800 \mathrm{rpm}$ and $400 \mathrm{hp}$ at $2000 \mathrm{rpm}$. For a complete list of S60G engine specifications and development work please refer to the DDC report in Appendix B.

The previous section compared the S60G with the S60 diesel from which it was derived; however, the diesel control vehicle in this project was not powered with a S60 diesel engine. Instead, the diesel control vehicle was powered with a 1984 Cummins NTC 350. It is acknowledged and accepted that comparisons between the LNG trucks and the diesel control are more anecdotal than scientific.

\section{Tractors}

The LNG-powered tractors and the diesel control tractor are described in Table 1.

Table 1. Description of LNG and Diesel Tractors

\begin{tabular}{|l|l|l|}
\hline & Diesel & LNG \\
\hline Chassis & 1984 Kenworth W900V & 1995 Freightliner FLD 120 \\
\hline Engine & $\begin{array}{l}1984 \mathrm{Cummins} \text { NTC 350 } \\
(350 \mathrm{hp})\end{array}$ & $\begin{array}{l}\text { Prototype DDC S60G } \\
(370 \mathrm{hp})\end{array}$ \\
\hline Transmission & Eaton 9-speed manual & Rockwell 10-speed manual \\
\hline Rear end & $4.33: 1 \mathrm{ratio}$ & $3.21: 1 \mathrm{ratio}$ \\
\hline Tire size & $11 \times 24.5$ & $275 / 80 \mathrm{R} 22.5$ \\
\hline Wheel base & $220 \mathrm{in}$. & $230 \mathrm{in}$. \\
\hline Front axle rating & $12,000 \mathrm{lb}$ & $12,000 \mathrm{lb}$ \\
\hline Rear axle rating & $38,000 \mathrm{lb}$ & $38,000 \mathrm{lb}$ \\
\hline Fuel tanks & 120 gal each $(\mathrm{x} 2)$ & 119 gal each $(\mathrm{x} 2)$ \\
\hline
\end{tabular}

\section{Natural Gas}

\section{Background}

Although emissions were not measured in this project, natural gas can provide significant reductions in regulated emissions, especially oxides of nitrogen $\left(\mathrm{NO}_{\mathrm{x}}\right)$ and particulate matter $(\mathrm{PM})^{1}$. This makes LNG particularly attractive for urban routes, where $\mathrm{NO}_{\mathrm{x}}$ and $\mathrm{PM}$ emissions are a major concern and fuel can be dispensed from a central fuel storage system. Natural gas is also one of the most abundant fuel sources in the United States, so its use in transportation is strategically sound.

LNG is a cryogenic liquid. At atmospheric pressure, it boils at approximately $-260^{\circ} \mathrm{F}$ and vaporizes rapidly. The gas is lighter than air and will rise from a spill or venting tank. Unless LNG is escaping in large quantities, it does not pool in a liquid form. LNG is a very dense form

\footnotetext{
${ }^{1}$ SAE paper \#981393, “Emissions from Trucks and Buses Powered by Cummins L-10 Natural Gas Engines," in State of Alternative Fuel Technologies, 1998, SAE order \#SP-1365; SAE paper \#973202, "Hybrid Electric Transit Bus," Viterna, Larry A., November 1997; Alternative Fuel Transit Buses: Final Results from the National Renewable Energy Laboratory Vehicle Evaluation Program, NREL/TP-425-20513, October 1996, Golden, CO: NREL.
} 
of natural gas - it allows more fuel to be stored on board, which increases vehicle range over compressed natural gas. Appendix C covers the properties of LNG and compares diesel and gasoline.

\section{Tank Design}

On-board fuel storage is considerably different between diesel and LNG. Standard diesel tanks are single-wall aluminum containers and cost in the hundreds of dollars, depending on size. Tanks for cryogenic LNG require double-wall construction from stainless steel with super insulation and vacuum inter-tank space. Typical tank pressures are between 20 to 150 psig, but the design must withstand more than two times that amount to compensate for heat gain when not in use. LNG fuel storage systems are significantly more complicated to design and manufacture and their cost is an order of magnitude greater than that of a diesel tank.

The weight of LNG is approximately $3.5 \mathrm{lb} / \mathrm{gal}$, compared to diesel at 7.6lb/gal. Unfortunately, the more complex LNG fuel tank is substantially heavier. In total, given the difference in tank design and fuel density, LNG-powered tractors have suffered a weight penalty.

\section{Engine Technology}

Current dedicated natural gas engine technology, which includes the DDC S60G, uses a throttle, a low compression ratio, and spark ignition. Inherent to this engine strategy is a thermal efficiency penalty of $15 \%$ or more versus a diesel-cycle engine. By comparison, the diesel engine does not use a throttle, has a high compression ratio and is ignited by heat of compression. The National Renewable Energy Laboratory (NREL), with the support of the U.S. Department of Energy (DOE), is sponsoring research that will potentially lead to natural gas engines with efficiencies similar to diesel engines. However, these new engine designs may take many years to perfect and commercialize.

\section{LNG Weathering}

One effect of LNG's cryogenic properties is unique, and important to understand, especially when LNG is to be used as a vehicle fuel. This effect, called "weathering" or "enrichment," is a phenomenon that arises from the fact that natural gas is a chemical mixture. LNG produced from pipeline gas has varying percentages of methane and other hydrocarbons. The methane content can vary from $92 \%-99 \%$. The other hydrocarbons found in natural gas are ethane $(1 \%-6 \%)$, propane $(1 \%-4 \%)$, butane $(0 \%-2 \%)$, and other compounds. Each chemical element or compound in the liquid vaporizes at its own unique boiling point. Consequently, over time, concentrations of the heavier hydrocarbons (such as ethane, propane, and butane) increase. Higher concentrations of these hydrocarbons will cause premature ignition and "knock." Because uncontrolled knock causes engine damage, LNG must be used before it becomes weathered. Recognizing this potential difficulty, Liquid Carbonic set out to manufacture 99.4\% pure methane LNG. With this high percentage of methane, LNG weathering cannot create harmful fuel mixtures because the potentially harmful constituents are largely absent. 


\section{Economics of LNG}

The most obvious economic comparison to make is fuel cost, because fuel is the second largest operational cost after labor. However, comparing the cost of LNG to that of diesel is not as straightforward as it might seem because: (1) distribution costs for LNG are not included in the fuel price as they are for diesel; (2) state tax rates are generally different for each fuel and vary from state to state; (3) federal tax rates are different for each fuel; and (4) fuel energy content is different for each fuel. Table 2 shows the national cost averages obtained by TRI from the Congressional Research Service and the Natural Gas Vehicle Coalition. The energy content is provided and was used to calculate the equivalent fuel cost in dollars per diesel equivalent gallon (DEG). A DEG is the quantity of fuel that has the same energy content as a gallon of diesel fuel (please see Appendix $\mathrm{C}$ for fuel specification).

Liquid Carbonic's LNG fuel cost was a little more competitive because they did not incur any distribution costs; the tractors were fueled on site. LNG fuel costs will vary dramatically by geographic region based on the distribution costs and state taxes.

It should also be mentioned that LNG costs have decreased since the project ended because of the Taxpayer Relief Act of 1997. This act, which allows transportation fuels to be taxed based on their energy content, changed the federal tax rate on LNG from $\$ 0.189$ per gallon $\$ 0.119$ per gallon.

Table 2. National Average LNG and Diesel Fuel Cost

\begin{tabular}{|c|c|c|c|c|c|c|c|}
\hline $\begin{array}{c}\text { Fuel } \\
\text { Type }\end{array}$ & $\begin{array}{c}\text { Energy } \\
\text { Content } \\
(\mathrm{Btu} / \mathrm{gal})\end{array}$ & $\begin{array}{c}\text { Fuel } \\
\text { Cost } \\
(\$ / \mathrm{gal})\end{array}$ & $\begin{array}{c}\text { Dist. } \\
\text { Cost } \\
(\$ / \mathrm{gal})\end{array}$ & $\begin{array}{c}\text { State } \\
\text { Tax } \\
(\$ / \mathrm{gal})\end{array}$ & $\begin{array}{c}\text { Federal } \\
\text { Tax } \\
(\$ / \mathrm{gal})\end{array}$ & $\begin{array}{c}\text { Total Fuel } \\
\text { Cost } \\
(\$ / \mathrm{gal})\end{array}$ & $\begin{array}{c}\text { Equivalent } \\
\text { Fuel Cost } \\
(\$ / D E G)\end{array}$ \\
\hline Diesel & 128,500 & 0.65 & - & 0.24 & 0.21 & 1.10 & 1.10 \\
\hline LNG & 76,000 & 0.35 & 0.10 & 0.18 & 0.25 & 0.88 & 1.49 \\
\hline
\end{tabular}

Following labor and fuel cost, capital investment is the next most important consideration to a fleet's profitability. At the time of this project, some of the natural gas engine assembly was done off-line. The low volume of natural gas engines did not justify the coordination, scheduling, and tooling changes required to completely manufacture the engines on the production assembly line. Rather, manufacturers partially assembled natural gas engines on the regular production line and completed them off-line. This off-line manufacturing process imposes a significant cost premium in the price of each engine. In the case of Liquid Carbonic, the total differential cost of the lease (broken down in Table 3) was $\$ 570$ per week over a comparable diesel.

Today, however, the demand for natural gas engines is higher. Thus it is more common for engine manufacturers to assemble them on the production line, which has reduced the differential costs between diesel and natural gas engines. 
Table 3. Truck Capital and Leasing Costs

\begin{tabular}{|l|c|c|}
\hline \multicolumn{1}{|c|}{ Item } & Original Value (\$) & Fixed/Week (\$) \\
\hline Base vehicle & 72,235 & 430 \\
\hline $\begin{array}{l}\text { LNG Power Modification } \\
\text { (provided by Detroit Diesel) }\end{array}$ & & \\
\hline Labor for installation & 28,785 & \\
\hline Engine & 29,597 & \\
\hline Fuel System/Tanks & 11,607 & \\
\hline $\begin{array}{l}\text { Installation materials } \\
\text { (custom hoses, fittings, etc.) }\end{array}$ & 4,949 & \\
\hline Federal excise tax & 9,314 & $\mathbf{1 7 0}$ \\
\hline Subtotal added costs & 84,252 & $\mathbf{1 , 0 0 0}$ \\
\hline Total & $\mathbf{1 5 6 , 4 8 7}$ & \\
\hline
\end{tabular}

\section{Driving Routes}

The trucks were regularly driven on two different routes. Liquid Carbonic attempted to rotate the vehicles, but the mileage accumulation at the end of the project was significantly different. The accumulated mileage totals are shown in Table 4, along with service dates.

Route 1 is a distance of 60 miles from the plant in Willis to the Houston Metro facility in Houston, Texas. The truck running this route averaged 480 miles per week. This route consisted of about $80 \%$ highway miles and $20 \%$ city miles. Route 2 ran once per week from Willis to Austin, Texas, a distance of 370 miles (round trip) consisting of about $60 \%$ highway and $40 \%$ city driving.

Table 4. Vehicle Service and Mileage Accumulation

\begin{tabular}{|c|c|c|c|}
\hline $\begin{array}{c}\text { Vehicle } \\
\text { Number }\end{array}$ & $\begin{array}{c}\text { Begin } \\
\text { Service } \\
\text { Date }\end{array}$ & $\begin{array}{c}\text { End } \\
\text { Service } \\
\text { Date }\end{array}$ & $\begin{array}{c}\text { Cumulative } \\
\text { Vehicle } \\
\text { Miles }\end{array}$ \\
\hline LNG1 & $7 / 20 / 94$ & $4 / 28 / 97$ & 18,664 \\
\hline LNG2 & $7 / 28 / 94$ & $5 / 1 / 97$ & 58,056 \\
\hline LNG5 & $4 / 1 / 95$ & $4 / 28 / 97$ & 9,220 \\
\hline DSL4 & $8 / 31 / 94$ & $4 / 29 / 97$ & 99,684 \\
\hline
\end{tabular}

\section{Fuel Economy}

The LNG trucks averaged about 2.8 miles per gallon of LNG, equating to about 4.7 miles per DEG. Table 5 compares the energy content, fuel economy and DEG fuel economy. 
Table 5. Energy Content and Fuel Economy

\begin{tabular}{|c|c|c|c|}
\hline $\begin{array}{c}\text { Vehicle } \\
\text { Number }\end{array}$ & $\begin{array}{c}\text { Energy } \\
\text { Content } \\
\text { (Btu/gal) }\end{array}$ & $\begin{array}{c}\text { Fuel } \\
\text { Economy } \\
\text { (mi./gal.) }\end{array}$ & $\begin{array}{c}\text { Diesel Equivalent } \\
\text { Fuel Economy } \\
\text { (mi./DEG) }\end{array}$ \\
\hline LNG1 & 76,000 & 2.6 & 4.3 \\
\hline LNG2 & 76,000 & 3.0 & 5.1 \\
\hline LNG5 & 76,000 & 2.9 & 4.9 \\
\hline DSL4 & 128,500 & 4.5 & 4.5 \\
\hline
\end{tabular}

\section{LNG Truck Downtime}

The LNG units were operated under a full-maintenance lease with RTMS; however, the S60G engine and fuel system repairs were handled under a separate servicing agreement. Stewart and Stevenson (S\&S), the local DDC distributor, performed all engine and fuel system repairs. Although this arrangement was necessary because of the developmental nature of the engines, it sometimes added to the vehicle downtime. Vehicle downtime is summarized in Appendix D.

The primary issues were power output and idle problems. Both of these problems stemmed from the throttle system. This system consisted of a Deltec ${ }^{\mathrm{TM}}$ throttle body, a Woodward ${ }^{\mathrm{TM}}$ actuator, a Woodward $^{\mathrm{TM}}$ controller (EPG), and the DDC engine controller (DDEC). The S60G throttle operation starts with an electronic signal from DDEC to EPG which, in turn, signals the actuator to adjust the throttle plate position. This system proved difficult to adjust throughout the project and varied among trucks. Further development by DDC is expected to solve the throttle system issues.

Another developmental problem identified was the engine head. Because of the characteristics of spark-ignited engines and natural gas, engine head temperatures exceeded the original design limits. Larger cooling passages were needed to ensure proper operation. S\&S was able to modify the production engine head, but this represented a significant portion of the downtime. The revised engine head provided the proper engine operating temperatures and have satisfactorily resolved the problem.

Aside from the aforementioned mechanical and electronic control problems, no LNG- specific components proved more repair-intensive or required more frequent replacement than their diesel counterparts.

\section{Conclusions and Lessons Learned}

This was a cooperative on-road development project (see Appendix B for complete development report) that led to a production, heavy-duty, natural gas engine by Detroit Diesel Corporation. At the same time, this project demonstrated that LNG can be a viable fuel for heavy-duty trucks and that it offers great promise as a clean, domestically produced alternative to diesel fuel. The combination of fuel capacity and mileage achieved in this project gave the LNG-powered tractor around $62 \%$ of the diesel unit range. The LNG fuel can significantly reduce regulated emissions, especially oxides of nitrogen $\left(\mathrm{NO}_{\mathrm{x}}\right)$ and particulate matter $(\mathrm{PM})$. This makes LNG particularly 
attractive for urban routes, because $\mathrm{NO}_{\mathrm{x}}$ and $\mathrm{PM}$ emissions are a major concern in urban areas. In addition, fuel can often be dispensed from a central fuel storage system in urban applications.

Although LNG fuel cost and availability were acceptable in this project, this was a unique situation; a "showcase" fleet for Liquid Carbonic that incurred no distribution costs. Because of the characteristics of LNG and the limited number of liquefaction plants, LNG distribution will not be feasible in some regions. Fuel costs for LNG and diesel will vary by geographic region, so fuel costs must be assessed on a regional basis. LNG did, however, get a tax break from the Taxpayer Relief Act of 1997, which made the federal tax on LNG \$0.119 per gallon. Prior to 1997, LNG's tax was $\$ 0.189$ per gallon, and diesel fuel is currently taxed at $\$ 0.243$.

Clearly a significant portion of the cost differential is a function of the lower volume of natural gas engines, on-board fuel tanks, fuel delivery systems, and natural-gas-specific components relative to the number of diesel engines and components produced. These costs have been and are currently defrayed by tax incentives and/or grants but these vary by region and must be considered on a case by case basis.

Liquid Carbonic had an advantage over most fleets that might experiment with LNG because, as a world-wide supplier of cryogenic liquids, it was already familiar with LNG. However, as a vehicle operator, Liquid Carbonic was typical of most fleets that lease because they are accustomed to someone else keeping the trucks maintained. Despite the best intentions of RTMS and Detroit Diesel in agreeing to service them through S\&S, the third-party service arrangements were a source of frustration and increased vehicle downtime for Liquid Carbonic. 


\section{Appendix A:}

\section{Texas Alternative Fuel Implementation Plan}

The following implementation plan was mandated by 1989 legislation:

After September 1, 1991 affected parties-state agencies with more than 15 vehicles, school districts with more than 50 buses, private fleets with more than 25 vehicles, and all metropolitan transit authorities - could not purchase or lease any vehicle not able to operate on an alternative fuel.

Alternative fuels were defined as natural gas, propane and electricity.

$30 \%$ of the fleet had to be converted by September 1, 1994; $50 \%$ by September 1, 1996; and $90 \%$ by September 1, 1998.

In 1992, Houston Metro had 1,200 transit vehicles and 300 support vehicles. 
Appendix B:

Development and Demonstration of the Detroit
Diesel Corporation Series 60 Natural Gas Engine:
Part I-Engine Development 


\title{
"DEVELOPMENT AND DEMONSTRATION OF THE DETROIT DIESEL CORPORATION SERIES 60 NATURAL GAS ENGINE: PART I - ENGINE DEVELOPMENT"
}

\author{
By \\ Roger Parry, Detroit Diesel Corporation \\ Geoffrey Hemsley, IMPCO Technologies, Inc. \\ Henry Modetz, Acurex Environmental Corporation
}

\begin{abstract}
The Series 60 natural gas engine (S60G) was developed by Detroit Diesel Corporation to fill a projected need for a low emission, heavy duty, high horsepower engine that could be successfully employed in over the road truck operations in California and elsewhere. The 6-cylinder, in-line engine of $12.7 \mathrm{~L}$ displacement was based on technology developed for the 4-cylinder, $8.5 \mathrm{~L}$ variant of the same basic design. The 4-cylinder version, the S50G, is now emissions-certified in California and has been submitted for Federal Certification as well.

The S60G was developed with better than 90 percent commonality with the S50G. Performance was increased from the $224 \mathrm{~kW}$ of the $S 50 \mathrm{G}$ to $298 \mathrm{~kW}$ maximum rating for the S60G. The S60G is projected to achieve below $2 \mathrm{~g}$ $\mathrm{NO}_{x}$ and $0.01 \mathrm{~g} \mathrm{PM}$ emissions on the transient test cycle. There are currently 10 units in field evaluation, with additional units pending. Laboratory and field evaluations have yet to reveal a major design constraint or concern. However, field units have exhibited high oil consumption in service as well as intermittent exhaust smoke related to oil control. Design changes for improved oil control, as well as other improvements, will be implemented in ficld units as they become available.
\end{abstract}

\section{INTRODUCTION}

According to projections from the California Air Resources Board (CARB), there are an estimated 77,315 heavy-duty trucks (vehicles whose gross vehicle weights [GVW] exceed $3,856 \mathrm{~kg}(8,500 \mathrm{lb})$ registered in California. CARB cstimates that 29 percent, or 22,400 , of these vehicles are Class 8 diesel trucks with a GVW in excess of $14,968 \mathrm{~kg}$ $(33,000 \mathrm{lb})$. These Class 8 trucks accumulate more than 8.4 million miles per day in the South Coast Air Basin (SoCAB), emitting up to 34 times the oxides of nitrogen $\left(\mathrm{NO}_{x}\right)$ that a passenger car emits, on a per-mile basis. Overall, Class 8 trucks account for about 20 percent of the mobile-source SoCAB $\mathrm{NO}_{x}$ inventory.
As a result, the South Coast Air Quality Management District (SCAQMD) emphasizes the use of low-emission alternative fuels in the transportation sector as an air quality attainment strategy, as outlined in the 1994 Air Quality Management Plan (AQMP). Both the proposed Federal Implementation Plan (FIP) and the proposed State Implementation Plan (SIP) contain stringent emissions standards for heavy-duty trucks. It is unlikely that conventional diesel-fueled heavy-duty engines can meet the emissions standards set forth in the AQMP and FIP/SIP, while it is believed that alternative-fueled heavy-duty engines can.

The SCAQMD, therefore, has sponsored the development and demonstrations of alternative-fueled heavyduty engines beginning in 1988 with the Methanol HeavyDuty Truck Demonstration. In 1990, the SCAQMD joined with the California Energy Commission (CEC), the Southern California Gas Company (SoCalGas), and, later, the U.S. Department of Energy (DOE) through the National Renewable Energy Laboratory (NREL) and the Trucking Research Institute (TRI), to develop and demonstrate compressed natural gas (CNG) heavy-duty engines, specifically, the 3406 made by Caterpillar, Inc., and the Series 60, manufactured by Detroit Diesel Corporation. This paper details the development of the S60G; the development and demonstration of the 3406 was reported earlier (Reference 1).

To meet the overall demonstration program objectives, the specific objectives for development and demonstration of the S60G engine were the following:

- Develop a Series 60, 6-cylinder, 12.7L engine based on the Series 50,4-cylinder, $8.5 \mathrm{~L}$ natural gas engine

- Achieve the target emission levels of $3.35 \mathrm{~g} / \mathrm{kWh}$ ( $2.5 \mathrm{~g} / \mathrm{bhp}-\mathrm{hr}) \quad \mathrm{CO}, 3.35 \mathrm{~g} / \mathrm{kWh}(2.5 \mathrm{~g} / \mathrm{bhp}-\mathrm{hr})$ $\mathrm{NO}_{x}$, and $0.027 \mathrm{~g} / \mathrm{kWh}(0.02 \mathrm{~g} / \mathrm{bhp}-\mathrm{hr}) \mathrm{PM}$

- Endow the engine with performance and driveability acceptable to the commercial, heavyduty truck market

- Demonstrate the acceptability and durability of this product in actual fleet operations while maintaining emissions performance 


\section{ENGINE DESIGN}

The S60G was conceived in September 1994. The design approach adopted was to use as much technology as possible that had evolved from the S50G (Reference 1) as the engines were identical in cross section and only differed in length (to accommodate two additional cylinders in the Series 60). Initial review showed that 90 percent or more of the parts could be used from the S50G, or the modifications employed to produce S50G components from base diesel engine parts could produce S60G components as well. Because the engine was so similar to the diesel version, Detroit Diesel was able to complete the bulk of the assembly on the first S60G as well as all subsequent S60Gs on the production line that produces all Series 60 diesels. The benefits of producing the first natural gas engine on the production line were:

- Economy of production time on regular production facilities

- All quality control methods employed

- Employees see and become familiar with future production components, and can make suggestions for improvements based on production experience

- Promotes team spirit as employees on all levels are exposed and involved in research and development projects, the future direction of the company

DESIGN FEATURES AND SPECIFICATIONS The proposal contained in the original contract for Detroit Diesel to develop the S60G called for certain design features and specifications. Most of these were adopted in the developed engine. The proposed features and specifications are described in the following list:

- Air to air aftercooling of the inlet air charge to the same specifications as the S60 diesel

- Integral control of air/fuel (A/F) ratio, spark timing, and throttle by Detroit Diesel Electronic Control (DDEC)

- Lean-burn combustion, $A / F$ ratio in a $22: 1$ to $26: 1$ range (1.33 to $1.58 \lambda$ )

- Electronic control, control and diagnostic functions managed by DDEC exclusively

- Natural gas fuel admission upstream of the throttle plate, gas mixer location in front of the throttle body so the gas/air mixture is controlled by the throttle plate

- Moderate gas pressure, for compatibility with liquid natural gas (LNG) fuel systems (350 to $550 \mathrm{kPa}$ design input pressure at the final stage regulators)

- Electronic speed governing, idle, high idle, maximum engine speed and drive-by-wire capability controlled by DDEC; all-speed governing features from the diesel are replicated in the S60G engine

- Turbocharger control, wastegate for boost control and compressor bypass valve to reduce thrust loads imposed by compressor surge on rapid throttle closing

- Overboost protection via DDEC throttle override in case of wastegate failure
- High exhaust temperature protection via DDEC throttle override in case of detonation or fuel system failure

- Engine rating up to $298 \mathrm{~kW} @ 2,100 \mathrm{rpm}$ and peak torque of 1,508 N-m @ 1,200 rpm

- Electrical power, all the components on the S60G engine operate on 12 volt electrical power, including the DDEC (which can also operate on 24 volts)

- Exhaust aftertreatment was proposed; however, based on developmental experience with the S50G, it was anticipated that the S60G would meet emissions targets without a catalytic converter

PERFORMANCE-The power and torque ratings of the S60G were specified to match available diesel ratings. The ratings reproduced are:

- $261 \mathrm{~kW} @ 1,800$ rpm, 1,831 N-m of torque @ $1,200 \mathrm{rpm}$

- $276 \mathrm{~kW} @ 1,800 \mathrm{rpm}, 1,966 \mathrm{~N}$-m of torque @ $1,200 \mathrm{rpm}$

- 298 kW @ 2,100 rpm, 1,966 N-m of torque @ $1,200 \mathrm{rpm}$

Power, torque, and brake-specific fuel consumption of the diesel Series 60 engines with these ratings are shown in Figures 1, 2, and 3.

FUEL SPECIFICATION-Much concern over gas composition was generated by Detroit Diesel's experience at Denver RTD with the dual fuel Pilot Ignition Natural Gas

\section{DETRDIT DIESEL}

\section{Automotive Powe}

Model: Series $60-11.14$ Truck

Rating: 350 bhp $1800 \mathrm{r} / \mathrm{min}$

$1350 \mathrm{~b}$.4t $1200 \mathrm{r} / \mathrm{min} \quad$ Certification: 50 State 1994

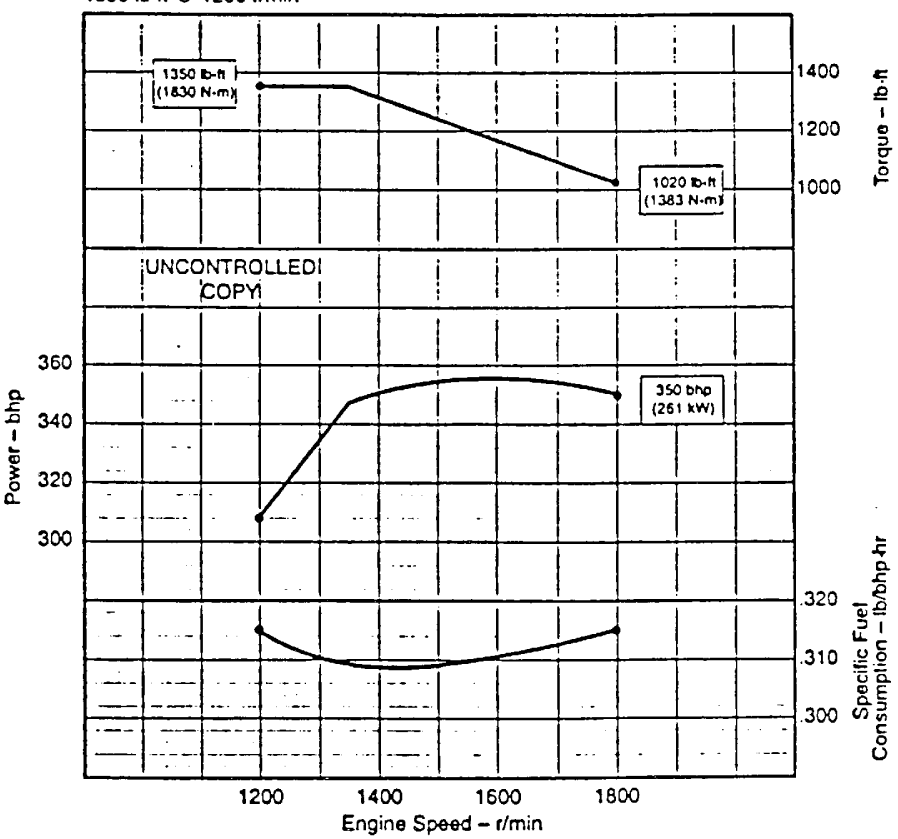

Figure 1. Series 60 Diesel $261 \mathrm{~kW}$ (350 bhp) Rating (Reproduced courtesy of Detroit Diesel Alternate Fuel Project Center) 


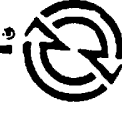

\section{Automotive Power}

Model: Series $60-12.7$ Truck

Rating: $370 \mathrm{bhp} 1800 \mathrm{r} / \mathrm{min}$

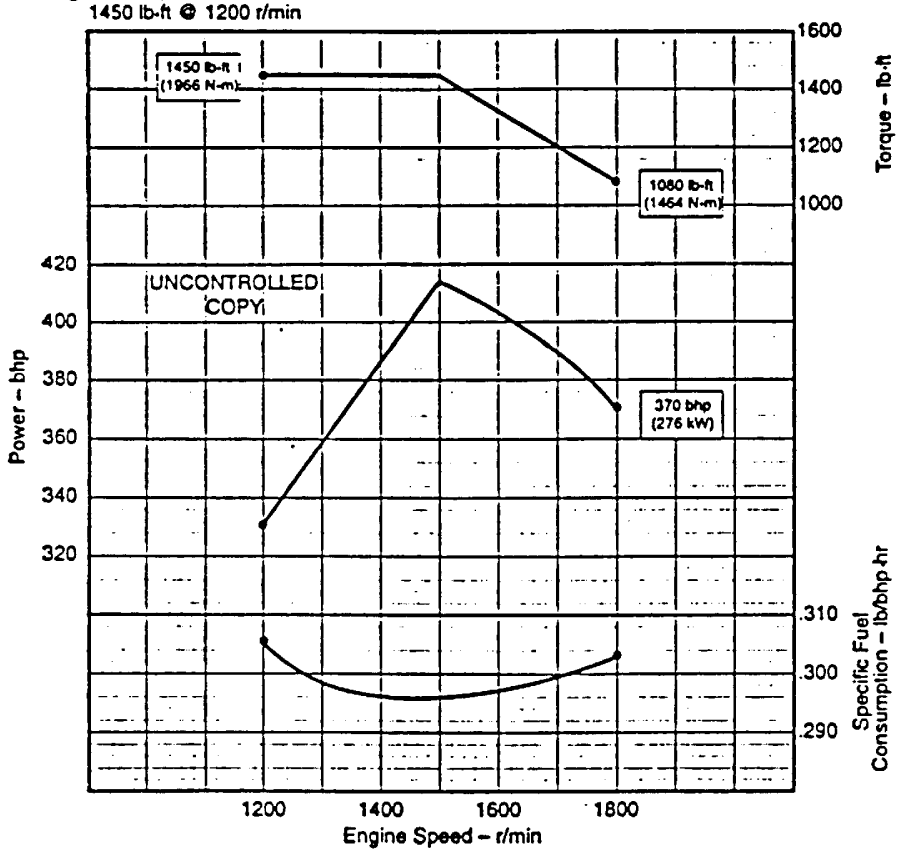

Figure 2. Series 60 Diesel $276 \mathrm{~kW}(370 \mathrm{bhp})$ Rating (Reproduced courtesy of Detroit Diesel Alternate Fuel Project Center)

(PING) engines. The amount of methane in the CNG fuel quantity of higher hydrocarbons (e.g., ethane, propane, and butane) and impurities (c.g., nitrogen, carbon dioxide, and varied between 86 and 98 percent in accordance with the water vapor) present. Several major engine failures were attributed to excessive amounts of non-methane hydrocarbons. An engine is originally calibrated for fuel delivery of a certain amount with a known energy density to achieve the rated power and torque. If a fuel is used that has a higher energy content in a given volume of fuel compared to the original fuel, it can develop power in excess of design levels. The extra power results in higher thermal and mechanical stress loads within the engine and can cause severe engine damage. To prevent such occurrences, Detroit Dicsel has determined a natural gas fuel specification that places limits on the amount of certain components commonly found in commercially available CNG. The same specification also applies to LNG, however, the nature of the process used to manufacture LNG eliminates water and results in 99.5 percent pure methane. Therefore, compliance with fuel specifications is generally an issue with CNG only. The complete specification is appended.

LUBRICATING OIL-One of the concerns of developing a new engine is the impact on the end user's maintenance costs. Engines that require uncommon or costly maintenance items will not fare well in the market place. To this end, the lubricating oil specifications for the S60G are based on commercially available $15 \mathrm{~W}-40$ oil

\section{Automotive Power}

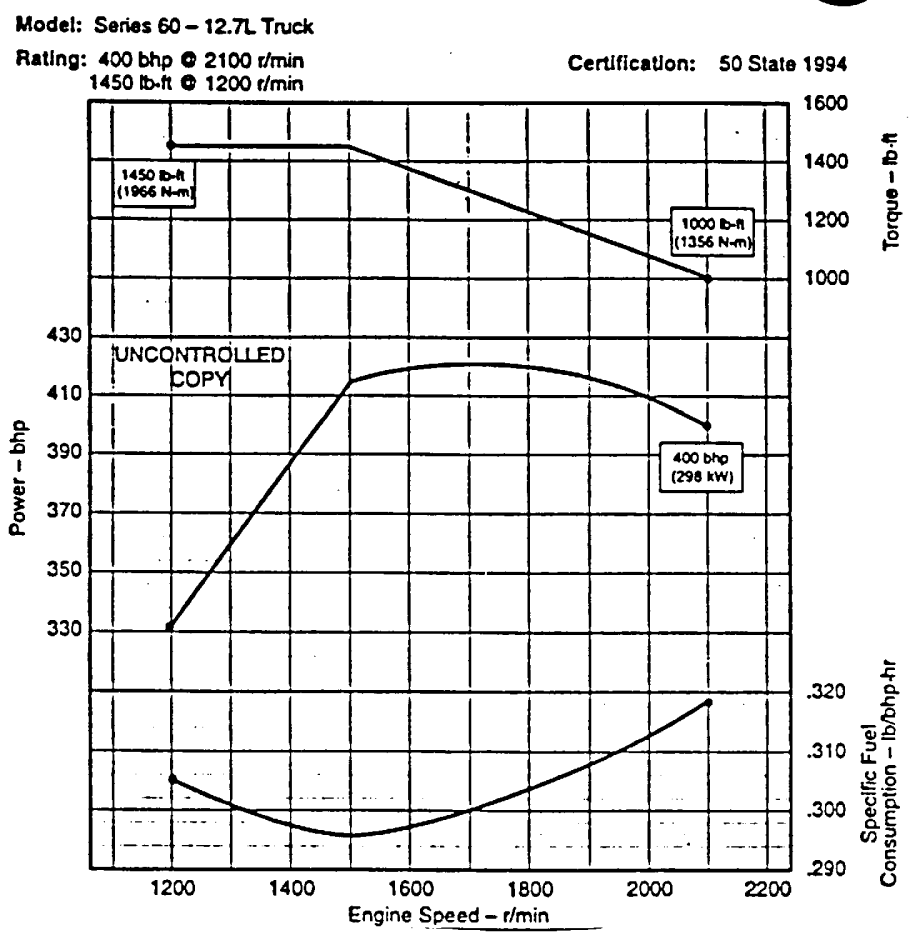

Figure 3. Series 60 Diesel $298 \mathrm{~kW}$ (400 bhp) Rating (Reproduced courtesy of Detroit Diesel Alternate Fuel Project Center)

marketed for natural gas engines by major oil producers. The oil change intervals and oil analysis values are somewhat conservative, and are based on available data. Oil analysis intervals may be extended as time and experience accumulates. The complete oil recommendations are appended.

\section{ENGINE DEVELOPMENT}

OVERVIEW-The S60G shares 90 percent of the parts used on the S50G and most parts are common to or modified from the diesel version of the engine.

Cylinder Block-The same block is used interchangeably for both the gas and diesel versions.

Crankshaft-The crankshaft is a diesel part modified for gas use. The diameter of the counterweights is reduced slightly to provide clearance for a shorter connecting rod.

Connecting Rod-The rod length is reduced to lower the compression ratio from the nominal 15:1 diesel ratio to the nominal 10:1 gas ratio. Six mm of material are removed from the piston pin saddle area yiclding the reduction in compression ratio.

Piston-The gas and diesel versions of the Series 60 share the same cylinder components as do the Series 50 gas and diesel versions. The dome and skirt are identical. The S50G and S60G both use 3.5-mm-wide fire rings, while the diesel has an option for $3.5-\mathrm{mm}$ rings with $2.5-\mathrm{mm}$ rings standard. Diesel engines are fitted with the wider rings for 
use in high-sulfur-fuel areas. The $3.5-\mathrm{mm}$ rings are used in the gas engines to better handle the higher combustion and exhaust temperatures.

Fire, Compression, and Oil Control Rings-The ring pack used on the developmental S60G is common with the S50 and S60 base diesel engines as noted above.

Cylinder Liners-All liners are common between the diesel and gas versions of the engines.

Cylinder Head-The cylinder head is one area of difference gas to diesel. The head is machined specially to accommodate the spark plug adapter replacing the injector hole tube, as shown in Figure 4.

As Figure 4 illustrates, the spark plug adapter is placed in the area usually occupied by the injector and injector hole tube. The spark plug adapter thus provides the spark plug access to the combustion chamber, seals oil inside the rocker cover and seals off the internal fuel passages present in a diesel cylinder head.

Spark Plug Adapter-Provides a seat and threads to mount a spark plug.

Spark Plug Tube-Provides access to the spark plugs as well as sealing the oil inside the rocker cover.

Spark Plugs-Various types have been and will be tried. The current plug is a Champion RC 78 PYP with platinum coated tips and $0.76-\mathrm{mm}$ gap.

Camshaft-The camshaft is a standard diesel cam but a 11-L grind is used in the 12.7-L S60G for less overlap.

Valves-The valves used are different from diesel in that the faces are Stellite as are the valve seat inserts to prevent valve seat "pound-in" or excessive wear. The developmental valve stem seals are of a different design and

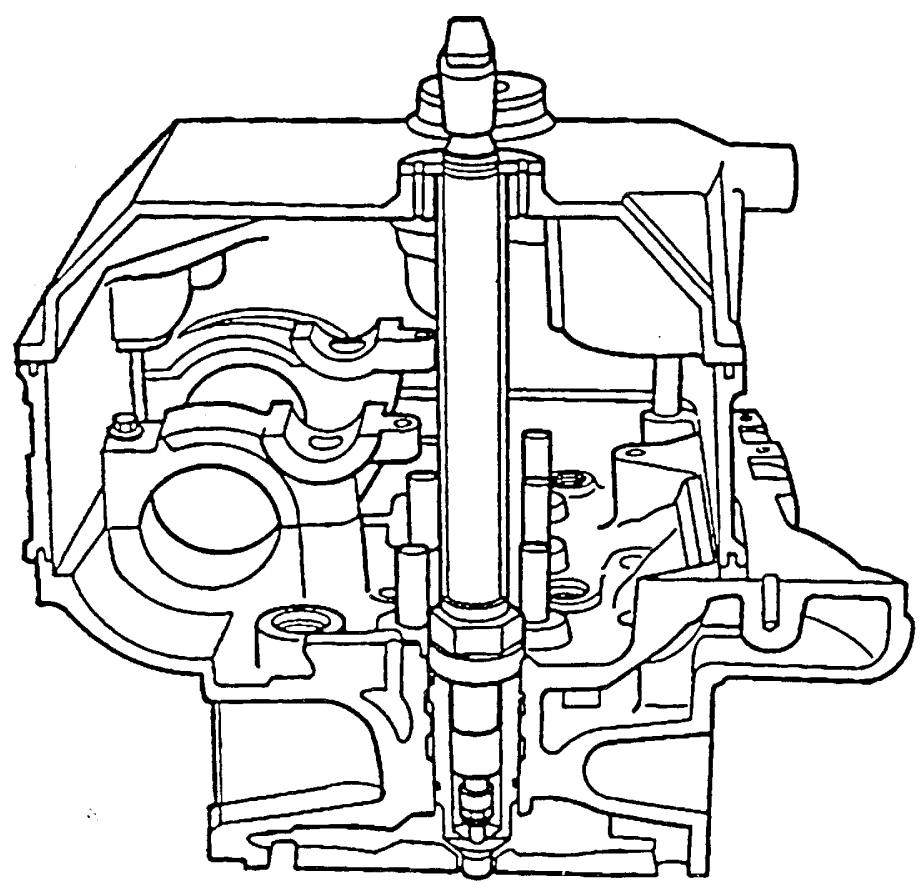

Figure 4. Cylinder Head Showing Spark Plug Adapter (Reproduced courtesy of Detroit Diesel Alternate Fuel Project Center) also "tighter" in the respect they reduce oil flow down the guides by 75 percent compared to diesel. The specified valve lash is also increased from $0.20 \mathrm{~mm}$ to $0.30 \mathrm{~mm}(0.008$ in to $0.012 \mathrm{in}$ ) on the intake valves, and from $0.61 \mathrm{~mm}$ to $0.71 \mathrm{~mm}$ ( 0.024 in to 0.028 in) on the exhaust valves.

Valve Operating Mechanism-The injector rocker arm is replaced by a cylindrical spacer that separates the exhaust arms and prevents uncontrolled oil flow through the lubrication holes in the rocker arm shaft.

Ignition System-The ignition system is a "direct fire" system consisting of Delco automotive coils, Packard Electric custom spark plug wires, and is operated by a proprietary interface with the DDEC.

Fuel System-The fuel system combines components from several manufacturers as well as custom features of DDEC control. The flow of gas to the low-pressure regulators is controlled by an electronic solenoid valve under DDEC control. The valve is opened when engine speed exceeds $60 \mathrm{rpm}$, making gas available only when the engine is operating. The low-pressure regulators are specially modified Impco Model E units used in parallel to provide adequate gas flow. The gas is introduced into the engine by a Deltec mixer; $\mathrm{A} / \mathrm{F}$ ratio is regulated by a Deltec control valve. The throttle is a Woodward integrated throttle valve and actuator governed by DDEC. DDEC has complete authority over ignition, fuel delivery, and throttle functions, as well as many diagnostic and data collection activities. Figure 5 shows the layout of fuel system.

Air System-The air system is a conventional turbocharged, aftercooled air delivery system. The turbocharger was selected for this application with assistance from Garrett Division of Allied Signal, and has special features not common to the diesel turbocharger. The turbocharger is sized to provide low end boost and reduce turbo lag, and is equipped with a wastegate to prevent

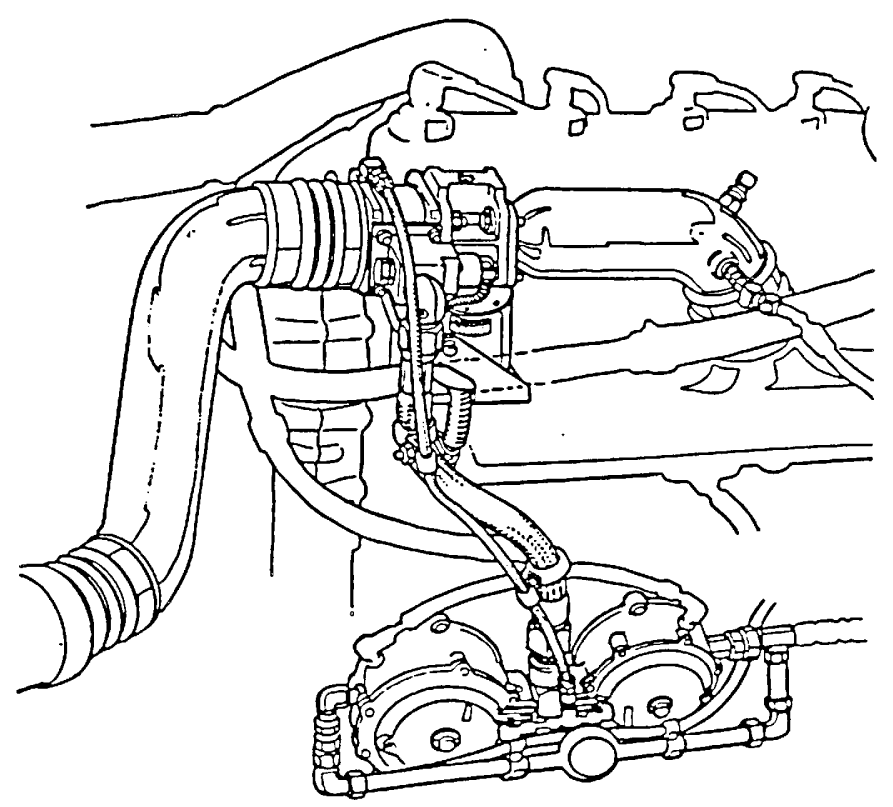

Figure 5. Layout of Fuel System (Reproduced courtesy of Detroit Diesel Alternate Fuel Project Center) 
overboost at high rpm. The wastegate senses compressor outlet pressure and limits boost to $124 \mathrm{kPa}$ above ambient pressure. In addition, there is a compressor bypass designed to reduce thrust load on the compressor wheel when rapid closing of the throttle traps air in the charge air cooler. When the throttle is closed suddenly, the rotational inertia of the turbocharger causes it to pressurize the column of air against the closed throttle. This can impose excessive thrust loads, negatively impacting durability of the turbocharger. To prevent excessive pressure spikes due to sudden throttle closure, a valve and passage are incorporated into the compressor intake, allowing the air to recirculate if boost exceeds a given pressure.

Additional protection against overboost is also provided through the DDEC software. If a certain level of boost is exceeded for a given amount of time, the throttle setting is reduced by the DDEC to prevent possible engine damage.

The original intake manifold was deemed unsuitable as the intake was not centrally located and unequal fuel and air distribution may result. A developmental manifold was fabricated from a production manifold by moving the intake back to a more central location. While not ideal, flow distribution was much improved over the standard intake manifold. Figure 6 shows the air flow improvement provided by the modified manifold compared to the best production manifold. Figure 7 schematically depicts the production and modified manifolds.

Cooling System - No changes were made to the cooling system.

Lubrication System-No changes were made to the lubricating system.

GEST STD MANIFOLD DMODIFIED MANIFOLD

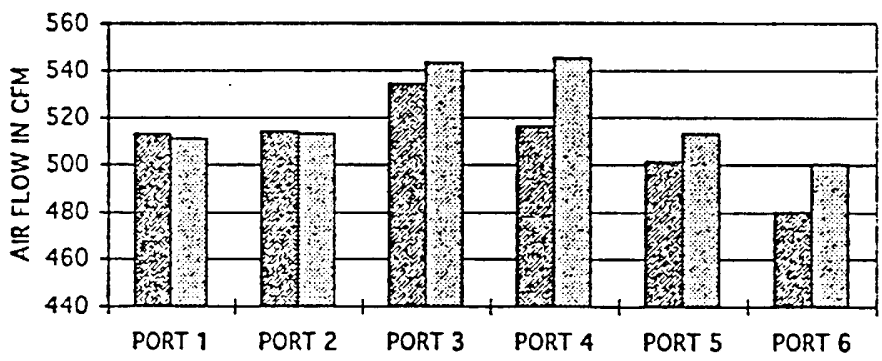

Figure 6. Production and Modified Manifold Air Flow Comparison (Reproduced courtesy of Detroit Diesel Alternate Fuel Project Center)

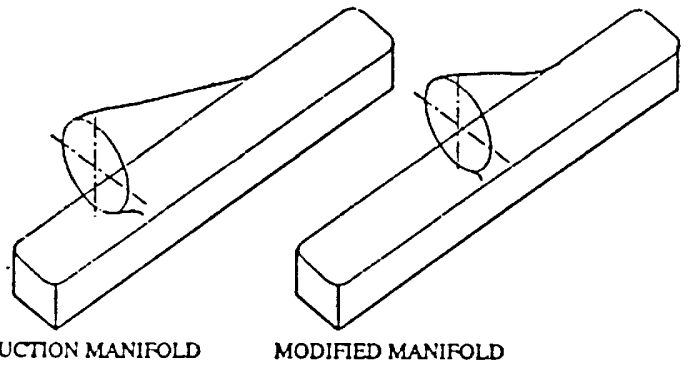

Figure 7. Production and Modified Manifold Geometry (Reproduced courtesy of Detroit Diesel Alternate Fuel Project Center)
Exhaust System-The only change made to the exhaust system was application of an insulating wrap to the exhaust manifold and turbine housing. This was done both to improve thermal efficiency and as a safety measure to protect mechanics not accustomed to the hotter exhaust surfaces inherent in a spark-ignited engine.

TECHNICAL APPROACH-The S60G engine is based on the Detroit Diesel Series 50 and 60 diesel engines designed for heavy duty trucking applications. Engine modifications for natural gas were focused on the cylinder head and fuel system. The cylinder block could be used without modification for the gas engine, as all parts required for the gas conversion were modifications of, or could be bolted on in place of the original diesel component. The cylinder block was considered strong enough as compression ratios and peak firing pressures for a spark-ignited engine would be lower. Some concern about the block was raised during the conceptual stage due to the increased heat rejection of a spark-ignited engine, but was dismissed since the energy would be absorbed in the piston, cylinder head, and exhaust manifold. Any increase in heat rejection to the block would be minimal and not affect its strength or durability.

The cylinder head required the most modifications as a spark plug had to be accommodated in place of the injector. A tidy solution was conceived where the original bore in the head for the injector is modified to accept a machined tube in place of the injector. The outer wall of the tube is machined to seal the fuel and coolant passages in the head used to feed and cool the injector. The inside of the tube is machined to seat a spark plug at the lower end. The electrode of the spark plug protrudes enough to be exposed for proper combustion and the tube is sealed to the fire deck of the head. Internally, the base of the tube is machined for a 14-mm spark plug with a compressible gasket. The spark plug adapter tube is shown in Figure 4. A concentric tube was also conceived to provide a passage for the spark plug wire to the outside of the valve rocker cover. The tube is fitted with O-ring seals in the spark plug adapter and is bolted to the top of the rocker cover.

Additional changes to the cylinder head consisted of replacing the valves and valve seats with a harder material to prevent valve "pound-in." Detroit Diesel experience with alternative fuel engines is that the exhaust contains very little of the residual hydrocarbons and soot associated with conventional fuels. These combustion byproducts serve to lubricate valve seats and valve seat inserts made of conventional materials. Unacceptable wear had been experienced with production valves and seats on earlier developmental gas- and alcohol-fueled engines. The solution was to increase the chrome and nickel content of the valve head material and provide Stellite seats in the cylinder head. The valve lash was also increased by $0.13 \mathrm{~mm}$ on both intake and exhaust to provide a margin against loss of valve lash due to valve seat and head wear.

The valve operating mechanism was changed by eliminating the injector rocker arm and replacing it with a sleeve/spacer to properly space the exhaust rocker arms and retain oil pressure in the rocker arm shaft. Valve stem seals 
were changed in recognition of the significant intake system vacuum levels inherent in throttled engines. A turbocharged diesel may see very slight vacuum during idle to power transitions but the duration and level are minimal. The S60G was expected to idle with an intake manifold pressure of approximately $30 \mathrm{kPa}$ and to develop cruise power with negative gauge pressure in the intake manifold. The developmental valve stem seals used were a stiff collar and ring type as opposed to the rubber cap and coil spring of the diesel. Tests indicated that the stiff collar seal reduced the passage of oil down the valve stem by 75 percent at idle.

One requirement of the gas engine was a lower compression ratio. The diesel compression ratio is $15: 1$ for proper auto ignition. A compression ratio this high in the converted engine is unsuitable because of the potential for a highly compressed homogeneous charge to detonate. A compression ratio of 10:1 was selected based on the lean combustion strategy. As design and manufacture of a new piston dome to reduce compression ratio is very costly for a prototype engine, other areas were explored. The approach adopted was to shorten the connecting rod by $6 \mathrm{~mm}$, thus achieving the desired 10:1 compression ratio. The only implication for the crankshaft was a required reduction in counterweight diameter. This is due to the reduced clearance between the bottom of the piston skirt and the crankshaft counterweight caused by shortening the connecting rod. To avoid any chance of contact, the production crankshaft is machined to reduce the counterweight diameter by $3 \mathrm{~mm}$. Additional machining is done to bring the crankshaft back into balance. The modified crankshaft can be used in a gas or diesel engine. Consideration will be given to a common crankshaft once sufficient production volumes are attained in the gas engine.

The connecting rod was shortened by removing $6 \mathrm{~mm}$ from the upper end in the piston pin saddle area, where structural strength would not be affected. The process change was minimal since only one dimension had to be changed in the rod machining, that of the pin radius to the center of the crankshaft hole. The only other part of the cylinder kit that required change to accommodate the lower compression ratio modification of the connecting rod was the pin bolt spacer. To retain the same pin bolt, a longer pin bolt spacer was designed. The longer spacer resulted in the same clamp load for the pin bolt as all other dimensions remained the same, e.g., bolt length and thread engagement.

To summarize the technical approach, internal parts developed for the S50G that are common to both engines were also used for the S60G. The engine-specific parts of the S60G, such as the cylinder head, were modified using the same dimensions and processes as for the S50G.

\section{MODIFICATIONS FOR S60G/PROBLEMS/ SOLUTIONS}

Turbocharger-The turbocharger had to be sized for the S60G based on the air flow required. A model was developed by Garret Division of Allied Signal to ratio up between the S50G turbo performance and S60G requirements. An interim bypass configuration, shown in Figure 8, was proposed for a model TV-51 which incorporated a wastegate but not a compressor bypass. A unit was installed on the developmental engine using a production exhaust manifold with a thermal barrier wrap added. The turbine housing was wrapped as well.

Intake Manifold-The intake manifold design is a major deviation from the S50G. The production 6-cylinder intake manifolds are highly asymmetric, whereas a production manifold with a central intake was available for use with the 4-cylinder S50G. The ideal manifold for a homogeneous charge engine provides uniform flow distribution to all cylinders. The production 6-cylinder manifold with the best flow distribution was selected to be modified for the S60G. The manifold's air intake, located between cylinders 2 and 3 , was sawed off and reattached (welded) at a central position. This manifold design served as a prototype for engine development. Figure 6 shows a comparison of air flow distribution of the production and modified manifolds. The modified manifold shows an improvement over the best production manifold but its air distribution is not ideal.

Ignition System-The ignition system used by the S50G was adapted to the $S 60 \mathrm{G}$ by adding an additional coil assembly and the additional software changes needed to drive six cylinders rather than four.

Fuel System-The fuel system for the S60G required major changes from the S50G. The gas flow requirements are higher for a $12.7 \mathrm{~L} \mathrm{S60G} \mathrm{compared} \mathrm{to} \mathrm{the} \mathrm{8.5L} \mathrm{S50G.}$ The fuel system used on the S50G did not have the capacity for the required additional flow of the S60G. Several options were considered. A 7-valve version of the current 6-valve, S50G GFI system was proposed but was not yet available. Two of the S50G, 6-valve GFI valves could be used in parallel but the extra expense of two computers in addition to DDEC was not practical. A system with sufficient capacity was available from IMPCO Technologies,

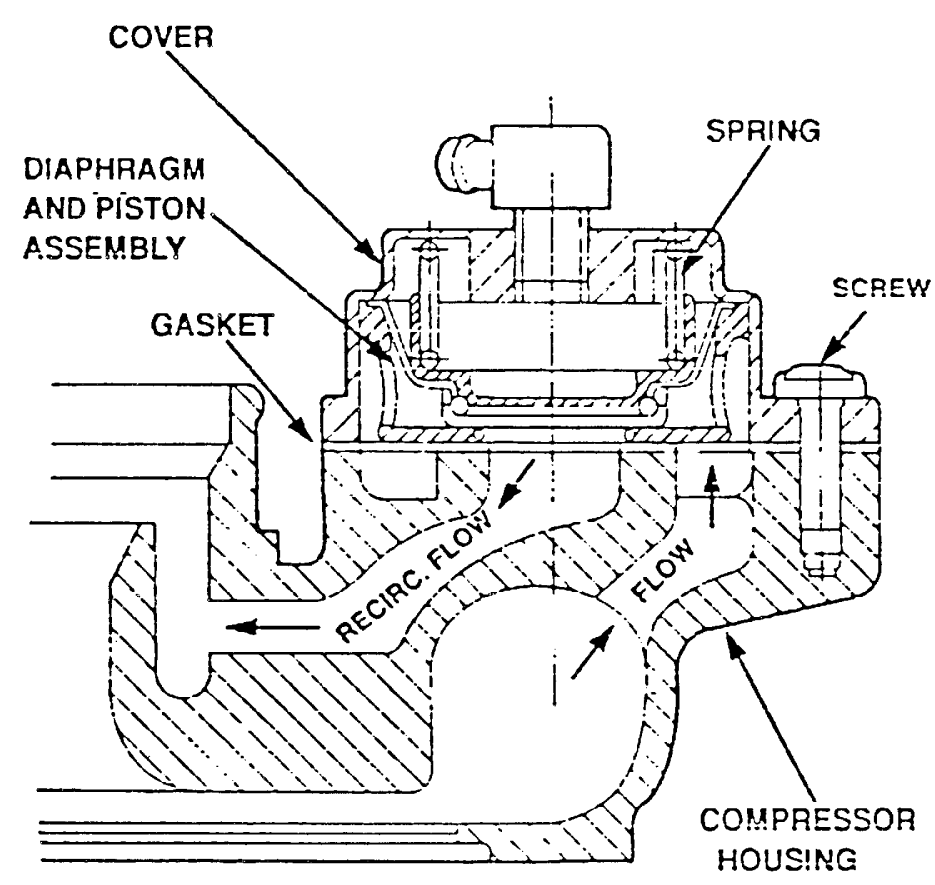

Figure 8. Turbocharger Compressor Bypass (Reproduced courtesy of Detroit Diesel Alternate Fuel Project Center) 
Inc. (IMPCO), but could not be pursued for non-technical reasons.

In parallel with evaluation of the IMPCO system for the S50G, Detroit Diesel evaluated a gas metering system from Deltec of Holland. The Deltec system was simple and had the flow capacity to deliver enough gas for the S60G. This system was also under consideration for the $\$ 30 \mathrm{G}$. Two IMPCO PE-7 low-pressure regulators designed for 0 to $2.17 \mathrm{MPa}$ gas input and 375 to $500 \mathrm{~Pa}$ output above boost up to $275 \mathrm{kPa}$ absolute regulate supply gas pressure to the Deltec system. The regulator outlet is plumbed into the Deltec control valve housing. The control valve is under DDEC control as a Pulse Width Modulated (PWM) device, and employs a stepper motor to adjust valve position. The gas is introduced into the air stream of the intake manifold through a mixer assembly with a pattern of metered holes around a venturi device. A mixer was chosen with a removable venturi insert to facilitate changes during engine development.

The throttle body was a $68-\mathrm{mm}$ bore Deltec component (a $60-\mathrm{mm}$ unit is used with the S50G) operated by a Woodward EPG controller and actuator. A tube was fabricated to connect the throttle body with the intake manifold.

\section{PERFORMANCE TESTING}

OVERVIEW-The engine was installed in Detroit Diesel's test facilities for performance, emissions, and durability testing. The test cell used is equipped with a General Electric IG705 Type TH water brake dynamometer rated to absorb $450 \mathrm{~kW}$ (600 bhp). The facility instrumentation measured:

- Engine speed

- Brake torque (N-m)

- Gas valve position

- Ignition timing

- A/F ratio

- Gas flowrate

- Air flowrate

- Turbo compressor pressure out

- Crankcase pressure

- Turbo compressor pressure in

- Turbo turbine pressure in

- Turbo turbine pressure out

- Manifold pressure

- Exhaust backpressure

- Fuel temperature in

- Gallery oil temperature

- Crankcase oil temperature

- Coolant temperature in

- Coolant temperature out

- Air meter temperature

- Turbo compressor temperature in

- Turbo compressor temperature out

- Intake manifold temperature

- Turbo turbine temperature in

- Turbo turbine temperature out

- Exhaust temperature \#1
- Exhaust temperature \#2

- Exhaust temperature \#3

- Exhaust temperature \#4

- Exhaust temperature \#5

- Exhaust temperature \#6

PERFORMANCE DEVELOPMENT-It was desired that the torque curves for the three rating variants of the S60G duplicate the corresponding diesel engine torque curves. The goals for the torque-speed relationships of the $261 \mathrm{~kW}$ (350 bhp), $276 \mathrm{~kW}$ (370 bhp), and $298 \mathrm{~kW}$ (400 bhp) engine ratings are shown in Table 1.

Calibration-Calibration parameters included gas valve position, ignition timing, throttle position, and boost pressure. The strategy used was to manipulate these parameters to first achieve the torque goals and then fine tune for emissions. The starting size of the gas mixer ring, venturi, metering orifice, and flow ports were all estimated based on theory and required verification on the test stand.

Performance goals were achieved at less than the maximum gas valve opening and with most gas valve settings in the map between 20 and 80 percent of full travel.

A timing strategy was established and the initial timing table was defined. Initial throttle and turbocharger wastegate calibrations were then determined. The initial calibrations resulted in maximum power being reached from 80 to 100 percent throttle position. Boost was 220 to 225 $\mathrm{kPa}$ absolute. Peak exhaust temperatures were 682 to $692^{\circ} \mathrm{C}$, a safe range. Cylinder $\# 3$ was typically the hottest, while cylinder \#4 was typically the coolest. The maximum temperature difference between cylinders \#3 and \#4 was $20^{\circ} \mathrm{C}$. The difference in exhaust temperatures is probably due to uneven charge distribution caused by the intake manifold geometry and intake pulsation. Detroit Diesel performed a manifold flow study, which resulted in recommendation of a divided manifold of three runners per side to isolate the intake pulses. A manifold of this design was produced but not tried due to time and funding constraints. Future development will take advantage of the improved manifold design.

Table 1. Torque Targets for the S60G

\begin{tabular}{|c|c|c|c|}
\hline & $\begin{array}{c}261 \mathrm{~kW} \\
(350 \mathrm{bhp}) @ \\
1,800 \mathrm{rpm}\end{array}$ & $\begin{array}{c}276 \mathrm{~kW} \\
(370 \mathrm{bhp}) @ \\
1,800 \mathrm{rpm}\end{array}$ & $\begin{array}{c}298 \mathrm{~kW} \\
(400 \mathrm{bhp}) @ \\
2,000 \mathrm{rpm}\end{array}$ \\
\hline $\begin{array}{l}\text { Speed } \\
\text { (rpm) }\end{array}$ & $\begin{array}{l}\text { Torque } \\
(\mathrm{N}-\mathrm{m})\end{array}$ & $\begin{array}{l}\text { Torque } \\
(\mathrm{N}-\mathrm{m})\end{array}$ & $\begin{array}{l}\text { Torque } \\
(\mathrm{N}-\mathrm{m})\end{array}$ \\
\hline 1,200 & 1,831 & 1,966 & 1,966 \\
\hline 1,350 & 1,831 & 1,966 & 1,966 \\
\hline 1,500 & 1,681 & 1,966 & 1,966 \\
\hline 1,650 & 1,534 & 1,715 & 1,814 \\
\hline 1,800 & 1,383 & 1,465 & 1,661 \\
\hline 1,950 & & & 1,509 \\
\hline 2,100 & & & 1,356 \\
\hline
\end{tabular}


PROBLEMS AND SOLUTIONS

Gas Filtration-Oil from the fuel got into the regulators and resulted in oil being drawn into the engine. The spark plugs started to foul with oil almost immediately and the engine began to misfire. Investigation showed the oil came from a leaking seal in the gas compressor. Further study disclosed the need for better filters in the gas feed line to the performance cell. This was accomplished with Raycor coalescing $0.3-\mu \mathrm{m}$ filters.

Lean Misfire-Spark plug failures occurred, the mode being a broken center electrode insulator, resulting in a compression leak. This was attributed to lean misfire under load at $A / F$ ratios 26:1 and higher. The lean limit margin was increased in the gas flow table. An A/F ratio meter was also added to the test cell to indicate precise $A / F$ ratio.

Overfueling-When the controls for the cell were set up, an unfortunate episode occurred in which the engine was overfueled, and developed $382 \mathrm{~kW} @$ 2,100 rpm for almost 12 minutes before cylinder kit damage occurred.

Spark Plug Tip Protrusion-During a study of peak Firing pressure work, it was discovered the spark plug protrusion into the combustion chamber was $1 \mathrm{~mm}$ less than designed. This was due to a dimensioning oversight that did not include the spark plug gasket with a crushed thickness of $1 \mathrm{~mm}$. Tests were run to determine the difference in emissions and none was found. However, it was shown the engine could run one $A / F$ ratio leaner with the designed spark plug protrusion. The spark plug adapter tubes were revised to provide the correct protrusion.

Throttle Linkage And Woodward EPG Controller Adjustment-The throttle used on the S50G is a Deltec throttle body operated by a Woodward Actuator in turn driven by a Woodward EPG driver. This operates the throttle based on signals from DDEC. The complete system was adopted for the S60G. Adjustment proved to be a lengthy process with unavoidable variation from engine to engine. Virtually every time a power problem arose, the linkage was suspect and reset. It was also found to be difficult to obtain a smooth roll-free idle with this system.
ENGINE DEVELOPMENT RESULTS-Many different tests were performed and developments occurred while the engine was in the test cell:

- Calibration of the DDEC

- Throttle tables

- Timing tables

- Fuel flow tables

- Torque tables

- Governor control tables

- Timing interface

- Fuel flow interface

- Monitoring interface

- Calibration/sizing of the Deltec fuel system

- Calibration/sizing of the IMPCO regulators

- Calibration of the Micro-Motion fuel measuring system

- Mapping of the turbocharger

- Calibration of the turbocharger wastegate

- Determination of peak firing pressures and pressure/ temperature curve during combustion.

- Development of new valve lash specifications

- Evaluation of new software iterations

- Evaluation of spark plug brands, types, coatings, and gap

- Evaluation of ignition systems

Power and Torque Results-Table 2 shows the actual rated power and torque-speed relationships for each engine rating alongside the corresponding specifications.

Engine Parameters at Full Load-Shown below are the actual $\log$ entries of all measured parameters during a typical run at full load April 26, 1994.
1. Engine speed
$2,100 \mathrm{rpm}$
2. Load
3. Gas valve position
4. Ignition timing
$1,355 \mathrm{~N}-\mathrm{m}(998.6 \mathrm{lb}-\mathrm{ft}, 400 \mathrm{hp})$
$640(0=\min ., 1,000=\max$.
$38^{\circ} \mathrm{BTC}$
A/F ratio
25.45:1
6. Gas flow
$1.072 \mathrm{~kg} / \mathrm{min}$
Air flow
$44.7 \mathrm{~L} / \mathrm{min}$
8. Turbo compressor pressure out

Table 2. Specified and Actual Engine Performance

\begin{tabular}{|c|c|c|c|c|c|c|}
\hline $\begin{array}{c}\text { Engine Rating } \\
\text { (kW @ rpm) }\end{array}$ & $\begin{array}{c}\text { Specified } \\
(261 @ 1,800)\end{array}$ & $\begin{array}{c}\text { Actual } \\
(261 @ 1,800)\end{array}$ & $\begin{array}{c}\text { Specified } \\
(276 @ 1,800)\end{array}$ & $\begin{array}{c}\text { Actual } \\
(276 @ 1,800)\end{array}$ & $\begin{array}{c}\text { Specified } \\
(298 @ 2,100)\end{array}$ & $\begin{array}{c}\text { Actual } \\
(298 @ 2,100)\end{array}$ \\
\hline $\begin{array}{l}\text { Speed } \\
\text { (rpm) }\end{array}$ & $\begin{array}{l}\text { Torque } \\
(\mathrm{N}-\mathrm{m})\end{array}$ & $\begin{array}{l}\text { Torque } \\
\text { (N-m) }\end{array}$ & $\begin{array}{l}\text { Torque } \\
\text { (N-m) }\end{array}$ & $\begin{array}{l}\text { Torque } \\
(\mathrm{N}-\mathrm{m})\end{array}$ & $\begin{array}{l}\text { Torque } \\
(\mathrm{N}-\mathrm{m})\end{array}$ & $\begin{array}{l}\text { Torque } \\
(\mathrm{N}-\mathrm{m})\end{array}$ \\
\hline 1,200 & 1,831 & N.A. ${ }^{a}$ & 1,966 & 1,966 & 1,966 & 1,980 \\
\hline 1,350 & 1,831 & N.A. & 1,966 & 1,966 & 1,966 & 1,959 \\
\hline 1,500 & 1,681 & N.A. & 1,966 & 1,966 & 1,966 & 1,949 \\
\hline 1,650 & 1,534 & N.A. & 1,715 & 1,715 & 1,814 & 1,802 \\
\hline 1,800 & 1,383 & 1,383 & 1,465 & 1,465 & 1,661 & 1,635 \\
\hline 1,950 & & & & & 1,509 & 1,502 \\
\hline 2,100 & & & & & 1,356 & 1,349 \\
\hline
\end{tabular}

${ }^{2}$ N.A. $=$ Not available. 
9. Crankcase pressure

$0.1 \mathrm{kPa}$

10. Turbo compressor pressure in

$-2.6 \mathrm{kPa}$

11. Turbo turbine pressure in

12. Turbo turbine pressure out

13. Manifold air pressure

14. Exhaust back pressure

15. Fuel temperature in

16. Gallery oil temperature

17. Crankcase oil temperature

18. Coolant temperature in

19. Coolant temperature out

20. Air meter temperature

21. Turbo compressor temperature in

22. Turbo compressor temperature out

23. Intake manifold temperature

24. Turbo turbine temperature in

25. Turbo turbine temperature out

26. Exhaust temperature \#1

27. Exhaust temperature \#2

28. Exhaust temperature \#3

29. Exhaust temperature \#4

30. Exhaust temperature \#5

31. Exhaust temperature \#6

\section{EMISSION TESTING}

TEST DESCRIPTION-Undiluted raw exhaust is sampled from the engine exhaust system via two sample trains. Particulates were not measured due to system downtime during the limited time available for emission testing.

$\underline{\mathrm{HC}}$ and NO$x$ Sample Train-The sample is filtered to remove any contaminants and routed to an oven via a heated sample line with a controlled temperature of $190^{\circ} \mathrm{C}$. Inside of the oven the sample is separated into two streams. A portion of the sample remains heated, passes through a heated pump and continues on to enter the HC analyzer. The remaining portion of the sample is drawn through a sample pump to a catalytic converter (reducing $\mathrm{NO}_{\mathbf{x}}$ to $\mathrm{NO}$ ) and a refrigerated bath which condenses out moisture from the sample by chilling it to $-4^{\circ} \mathrm{C}$. The sample then enters the $\mathrm{NO}_{\mathrm{x}}$ analyzer.

$\mathrm{CO}$ and $\mathrm{CO}_{2}$ Sample Train-The sample is filtered to remove any contaminants and is routed to the analyzer cabinet via a non-heated sample line. The sample is drawn through a refrigeration bath by a sample pump and is then separated into two parts, one entering the $\mathrm{CO}$ analyzer and the other entering the $\mathrm{CO}_{2}$ analyzer.

\section{EMISSIONS RESULTS} Table 3.

The results of steady-state emissions tests are shown in

Based on the steady-state performance, and the transient emission performance of the S50G, resulting in its CARB and EPA certification, it is reasonable to assume the S60G is capable of certification at $3.35 \mathrm{~g} / \mathrm{kWh}(2.5 \mathrm{~g} / \mathrm{bhp}-$ hr) $\mathrm{NO}_{x}$ and below $0.134 \mathrm{~g} / \mathrm{kWh}(0.1 \mathrm{~g} / \mathrm{bhp}$-hr $)$ PM. With additional improvements such as the divided intake manifold and temperature compensation software, the $\mathrm{NO}_{x}$ emissions may be reduced below $2.68 \mathrm{~g} / \mathrm{kWh}(2.0 \mathrm{~g} / \mathrm{bhp}-\mathrm{hr})$.

\section{DURABILITY TESTING}

OVERVIEW-A second S60G was constructed for durability testing. This engine was destined to be the first field-evaluation S60G for the Los Angeles Times, and was produced on the assembly line as were the first and all subsequent S60Gs. The completed engine was returned to the engineering lab for installation of the specific S60G components. The gas regulators to be shipped with the engine were mounted in the test cell, the gas components were installed on the intake manifold, and the wrapped turbocharger and exhaust manifolds were fitted. The ignition coils were mounted and the engine was started. After a standard 3-hour run-in, as specified in the S60 Diesel service manual, the durability test was started.

The rationale for using a new engine for durability testing was that the original S60G had accumulated over 200 hours of operation, while a new engine was desired for field evaluation with the Times. The 100 -hour durability test would uncover any defects in the new engine, while developmental efforts with the original engine could continue.

TEST DESCRIPTION-The durability test was conducted in the same test cell used for the development work so the dynamometer and instrumentation were the same. The engine was run for a total of 87.5 hours almost continuously. The load and speed were varied to simulate a truck duty cycle. The speed was varied from idle to 1,800 $\mathrm{rpm}$ and the load varied from none to $1,464 \mathrm{~N}-\mathrm{m}$. The engine was constantly monitored and no significant incident occurred during the durability test. The durability test was terminated at 87.5 hours for the engine to be shipped to Los Angeles for installation in the Times tractor. The schedule was dictated by a commitment for the completed CNG tractor to be displayed in the 1994 International Trucking Show.

\section{S60G PROGRAM RESULTS}

The program achieved its primary objective in that there are or will be at least 12 S60G-powered Class 8 trucks in daily operation, four of them in California. These engines have demonstrated the potential for low emissions, and overall feasibility of natural gas as a heavy-duty trucking fuel.

The demonstration fleet now comprises the original unit at the Los Angeles Times, Wal-Mart Stores, Inc. with one unit, and Unocal Corporation with one unit, all under the management of Acurex Environmental Corporation on behalf of the project sponsors. Los Angeles County Sanitation is now operating a S60G-powered refuse truck fueled with compressed landfill gas, on which Acurex Environmental is also collecting operations and maintenance data.

In addition, seven more units have been placed in fleets by Detroit Diesel, with up to 12 units pending. Liquid Carbonic operates five units in the Houston area. Gorden 
Table 3. Steady-State Emissions Results

\begin{tabular}{|c|c|c|c|c|c|}
\hline Emissions & $10 \%$ load & $25 \%$ load & $50 \%$ load & $75 \%$ load & $100 \%$ load \\
\hline \multicolumn{6}{|c|}{ Engine Rating, 261 kW @ 1,800 rpm } \\
\hline \multicolumn{6}{|c|}{ Brake-Specific Emissions @ 1,350 rpm (g/kWh) } \\
\hline $\mathrm{NO}_{\mathbf{x}}$ & 0.165 & 0.141 & 0.438 & 1.480 & 3.571 \\
\hline $\mathrm{HC}$ & 191.9 & 31.0 & 12.1 & 7.9 & 9.8 \\
\hline $\mathrm{CO}$ & 14.55 & 4.88 & 2.93 & 2.55 & 2.78 \\
\hline $\mathrm{CO}_{2}$ & 1,051 & 761 & 651 & 570 & 565 \\
\hline \multicolumn{6}{|c|}{ Brake-Specific Emissions@ 1,800 rpm (g/kWh) } \\
\hline $\mathrm{NO}_{\mathbf{x}}$ & 0.209 & 0.149 & 0.211 & 0.661 & 1.555 \\
\hline $\mathrm{HC}$ & 203.1 & 90.4 & 24.0 & 11.5 & 7.7 \\
\hline $\mathrm{CO}$ & 18.28 & 10.01 & 3.84 & 3.22 & 3.19 \\
\hline $\mathrm{CO}_{2}$ & 1,227 & 869 & 642 & 621 & 596 \\
\hline \multicolumn{6}{|c|}{ Engine Rating, 278 kW @ 1,800 rpm } \\
\hline \multicolumn{6}{|c|}{ Brake-Specific Emissions @ 1,200 rpm (g/kWh) } \\
\hline $\mathrm{NO}_{x}$ & 0.430 & 0.790 & 1.465 & 3.480 & 8.913 \\
\hline $\mathrm{HC}$ & 83.0 & 17.9 & 8.7 & 9.1 & 11.2 \\
\hline $\mathrm{CO}$ & 9.53 & 3.27 & 2.47 & 2.42 & 2.55 \\
\hline $\mathrm{CO}_{2}$ & 897 & 612 & 524 & 501 & 492 \\
\hline \multicolumn{6}{|c|}{ Brake-Specific Emissions @ 1,800 rpm (g/kWh) } \\
\hline $\mathrm{NO}_{\mathbf{x}}$ & 0.216 & 0.248 & 0.424 & 0.684 & 2.463 \\
\hline $\mathrm{HC}$ & 75.3 & 25.9 & 15.4 & 10.8 & 6.08 \\
\hline $\mathrm{CO}$ & 11.05 & 4.75 & 3.29 & 2.933 & 3.074 \\
\hline $\mathrm{CO}_{2}$ & 1,032 & 752 & 630 & 558 & 551 \\
\hline
\end{tabular}

Foods, a Michigan based food service company, operates one unit with fuel supplicd by Liquid Carbonic.

The trucks in service are demonstrating commercially acceptable operation as far as starting, driveability and performance. As anticipated, the results of day to day running in the real world are indicating the areas where more development is required.

The market potential of a low-emissions, heavy-duty truck engine is expected to improve as long as there are government mandates in areas of non-attainment in air quality or indeed in areas of concentrated population density. The long-term success of the low-emission engine will, however, depend on how well it compares both technically and economically to the technology it proposes to augment or replace.

\section{RECOMNENDATIONS}

The following recommendations result from areas that were found in need of further development as laboratory and field evaluations proceeded.

PERFORM FURTHER INTAKE MANIFOLD TESTING-The potential exists for better fuel economy, lower emissions, cooler operation in the cylinders, and improved exhaust flow by continued development of the intake manifold. An improved prototype has been constructed which should be used to show an improvement or strengthen confidence in the current design.

INVESTIGATE OIL CONSUMPTION-It is apparent that the $S 60 G$ operating conditions affecting oil control are sufficiently different from the diesel to require different components and that accepted diesel design practices may not be correct for a spark-ignited natural gas engine. When it became operational in the field, the Los Angeles Times engine exhibited unexpectedly high oil consumption and, under some conditions, heavy exhaust smoke. Similar results were experienced with other field units as they became operational. The oil control aspects of the piston, skirt, and ring areas need to be explored, and the intake valve stem oil consumption path should be reexamined.

\section{REFERENCE}

1. "Alternative-fueled Truck Demonstration Natural Gas Program: Caterpillar G3406LE Development and Demonstration," Acurex Environmental Final Report FR-94-123, Acurex Environmental Corporation, Mountain View, California, January 31, 1995. 


\section{NOMENCLATURE}

bhp Brake horsepower

BTC Before top center

CARB California Air Resources Board

CNG Compressed natural gas

$\mathrm{CO}$ Carbon monoxide

$\mathrm{CO}_{2} \quad$ Carbon dioxide

DDEC Detroit Diesel Electronic Control

EPA United States Environmental Protection Agency

$\mathrm{g} / \mathrm{bhp}$-hr Grams per brake horsepower hour

$\mathrm{g} / \mathrm{kWh} \quad$ Grams per brake kilowatt hour

hp Horsepower

$\mathrm{kPa} \quad$ Kilopascal

$\mathrm{kW} \quad$ Kilowatt

L Liter

lb-ft Pound-foot

LNG Liquefied natural gas

max. Maximum

min Minute

min. Minimum mm Millimeter

$\mathrm{MPa} \quad$ Megapascal

$\mathrm{N}$-m Newton-meters

$\mathrm{NO}_{x} \quad$ Oxides of nitrogen

PM Particulate matter

PWM Pulse width modulated

rpm Revolutions per minute

RTD Rapid Transit District

S30G Series 30 Natural Gas Engine

S50G Series 50 Natural Gas Engine

S60G Series 60 Natural Gas Engine

\section{ACKNOWLEDGMENTS}

The authors wish to acknowledge the support of the sponsors of the development of the $S 60 \mathrm{G}$ heavy-duty engine. In particular, we appreciate the enthusiastic support and guidance of Mr. Jerry Wiens, of CEC, Ms. Cindy Sullivan, of SCAQMD, Mr. Henry Mak, of SoCalGas, Mr. Mark Riechers, formerly with NREL and now at AVL, Mr. Paul Norton, of NREL, and Mr. William Peerenboom, of TRI. 


\section{Appendix C:}

\section{Fuel Property Comparison-LNG, Diesel, and Gasoline}

The table below compares the physical properties of LNG, diesel, and gasoline. Various values are given for the same parameters to illustrate that nearly all these parameters vary with changes in the chemical content of LNG. Properties of gasoline and diesel also vary with composition.

\begin{tabular}{|l|l|l|l|}
\hline Property & LNG & Diesel & Gasoline \\
\hline $\begin{array}{l}\text { Specific gravity } \\
\text { (vapor) }\end{array}$ & 0.6 & $4-6$ & $2-4$ \\
\hline $\begin{array}{l}\text { Specific gravity } \\
\text { (liquid) }\end{array}$ & 0.42 & 0.85 & 0.74 \\
\hline $\begin{array}{l}\text { Density, lb/gal, } \\
\text { Acurex }^{1}\end{array}$ & 3.4 & & \\
MVE $^{2}$ & 3.5 & 7.0 & 6.2 \\
\hline $\begin{array}{l}\text { Energy content, } \\
\text { Btu/lb, Acurex }\end{array}$ & $21,500^{3}$ & 7.3 & 6.2 \\
\hline $\begin{array}{l}\text { Btu/gal, Acurex } \\
\text { Bechtold }\end{array}$ & 73,000 & 18,300 & 18,900 \\
\hline $\begin{array}{l}\text { Relative fuel } \\
\text { volume (DEG), }\end{array}$ & 76,000 & 128,100 & 117,200 \\
Acurex & 1.7 & $126,000-131,000$ & $109,000-119,000$ \\
\hline $\begin{array}{l}\text { Flammability } \\
\text { limits, \% }\end{array}$ & & 1.0 & \\
MVE & $5-15$ & & 1.1 \\
Bechtold & $5-15$ & $0.5-4.1$ & \\
\hline $\begin{array}{l}\text { Auto ignition } \\
\text { temperature, }{ }^{\circ} \mathrm{F}\end{array}$ & & $1-6$ & $1.0-7.6$ \\
MVE $_{\text {Bechtold }}$ & $1,000-2,000$ & 500 & $1.4-7.6$ \\
\hline $\begin{array}{l}\text { Stoichiometric air- } \\
\text { fuel, Bechtold }\end{array}$ & 1,004 & 600 & $442-880$ \\
\hline
\end{tabular}

1. LNG Vehicle Technology, Economics and Safety Assessment, Acurex Environmental Corporation, February 1994.

2. "Liquid Natural Gas Fuel Systems," Minnesota Valley Engineering (MVE) pamphlet.

3. Value at $20 \mathrm{psig}$ and $-238^{\circ} \mathrm{F}$.

4. Bechtold, R.L., Alternative Fuels Guidebook, Society of Automotive Engineers, Warrendale, PA, 1997.

The above references use other primary references as sources for the values listed here. 


\section{Appendix D:}

\section{LNG Tractor Downtime Log}

\begin{tabular}{|c|c|c|c|c|}
\hline Unit & Date In & Complete & Comments & Downtime \\
\hline LNG5 & $05-18-95$ & $05-19-95$ & Low power & 1 day \\
\hline LNG5 & $08-07-95$ & $08-12-97$ & Low power & 5 days \\
\hline LNG5 & $11-14-95$ & $11-21-95$ & Update head problems & 7 days \\
\hline LNG5 & $02-20-96$ & $02-27-96$ & Check engine & 7 days \\
\hline LNG5 & 03-04-96 & $03-14-96$ & Running rough & 10 days \\
\hline LNG5 & $09-27-96$ & $09-30-96$ & Loss of power & 3 days \\
\hline LNG5 & $01-05-97$ & $01-13-97$ & Loss of power & 7 days \\
\hline LNG5 & $02-26-97$ & 03-14-97 & No power & 16 days \\
\hline LNG1 & $03-24-95$ & $04-06-95$ & Low power & 13 days \\
\hline LNG1 & $08-29-95$ & $08-30-95$ & Cruise control & 1 day \\
\hline LNG1 & $10-06-95$ & $10-17-95$ & Throttle idle & 11 days \\
\hline LNG1 & $11-21-95$ & $11-29-95$ & Update head problem & 7 days \\
\hline LNG1 & $12-28-95$ & $01-05-96$ & $\begin{array}{c}\text { Pressure, bad sensor, rough } \\
\text { engine }\end{array}$ & 8 days \\
\hline LNG1 & $01-29-96$ & $01-30-96$ & Hose & 1 day \\
\hline LNG1 & $04-15-96$ & 04-18-96 & Backfiring & 3 days \\
\hline LNG1 & $02-21-97$ & $02-25-97$ & No power & 4 days \\
\hline LNG1 & 03-20-97 & $03-21-97$ & No power & 1 day \\
\hline LNG1 & $05-13-97$ & $05-14-97$ & Campaign & 1 day \\
\hline LNG2 & $09-28-95$ & $10-07-95$ & Won't idle & 9 days \\
\hline LNG2 & $11-21-95$ & $12-01-95$ & Update head & 10 days \\
\hline LNG2 & $02-05-96$ & $02-09-96$ & Fuel leak & 4 days \\
\hline LNG2 & 03-04-96 & $03-08-96$ & Won't crank & 4 days \\
\hline LNG2 & $03-15-96$ & $03-19-96$ & Low power & 4 days \\
\hline LNG2 & $06-09-96$ & $06-10-96$ & Engine missing and surging & 1 day \\
\hline LNG2 & $08-23-96$ & $08-26-96$ & Engine missing & 3 days \\
\hline LNG2 & $12-05-96$ & $12-06-96$ & Broken air hose and manifold & \\
\hline
\end{tabular}




\section{REPORT DOCUMENTATION PAGE}

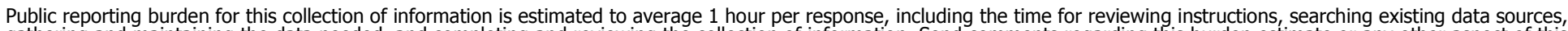

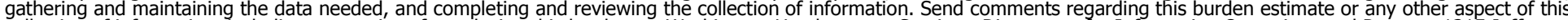

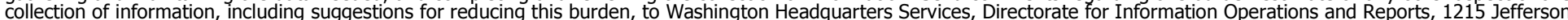

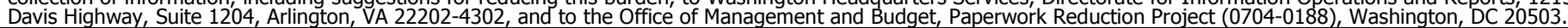

Davis Highway, Suite 1204, Arlington, VA 22202-4302, and to the Office of Management and Budget, Paperwork Reduction Project (0704-0188), Washington, DC 20503.

\begin{tabular}{|l|l|l|}
\hline 1. AGENCY USE ONLY (Leave blank) & $\begin{array}{c}\text { 2. REPORT DATE } \\
\text { July } 1999\end{array}$ & $\begin{array}{l}\text { 3. REPORT TYPE AND DATES COVERED } \\
\text { Subcontract report }\end{array}$ \\
\hline
\end{tabular}

4. TITLE AND SUBTITLE

Using LNG as a Fuel in Heavy-Duty Tractors

5. FUNDING NUMBERS

6. AUTHOR(S)

Liquid Carbonic, Inc. and the Trucking Research Institute

7. PERFORMING ORGANIZATION NAME(S) AND ADDRESS(ES)

Liquid Carbonic, Inc., Willis, TX

Trucking Research Institute, 2200 Mill Road

Alexandria, VA 22314-4677

9. SPONSORING/MONITORING AGENCY NAME(S) AND ADDRESS(ES)

National Renewable Energy Laboratory

1617 Cole Blvd.

Golden, CO 80401-3393

FU913310

8. PERFORMING ORGANIZATION

REPORT NUMBER

10. SPONSORING/MONITORING AGENCY REPORT NUMBER

SR-540-24146

11. SUPPLEMENTARY NOTES

NREL Technical Monitor: M. Frailey

12a. DISTRIBUTION/AVAILABILITY STATEMENT

National Technical Information Service

12b. DISTRIBUTION CODE

U.S. Department of Commerce

5285 Port Royal Road

Springfield, VA 22161

13. ABSTRACT (Maximum 200 words)

Recognizing the lack of operational data on alternative fuel heavy-truck trucks, NREL contracted with the Trucking Research Institute (TRI) in 1994 to obtain a cooperative agreement with Liquid Carbonic. The purpose of this agreement was to (1) purchase and operate liquid natural gas- (LNG-) powered heavy-duty tractor-trailers with prototype Detroit Diesel Corporation (DDC) Series 60 natural gas (S60G) engines in over-the-road commercial service applications; and (2) collect and provide operational data to DDC to facilitate the onroad prototype development of the engine and to NREL for the Alternative Fuels Data Center.

The vehicles operated from August 1994 through April of 1997 and led to a commercially available, emissions-certified S60G in 1998.

This report briefly documents the engine development, the operational characteristics of LNG, and the lessons learned during the project.

14. SUBJECT TERMS

Liquefied natural gas, alternative fuels, heavy-duty trucks, emissions

17. SECURITY CLASSIFICATION OF REPORT
18. SECURITY CLASSIFICATION OF THIS PAGE
19. SECURITY CLASSIFICATION OF ABSTRACT
15. NUMBER OF PAGES

28

16. PRICE CODE

20. LIMITATION OF ABSTRACT

Standard Form 298 (Rev. 2-89) Prescribed by ANSI Std. Z39-18

NSN 7540-01-280-5500 